Article received on 13 February 2013

Article accepted on 15 February 2013

UDC: $78.038 .42(497.11) ; 78.071 .1: 929(497.11)$

\title{
THE RECEPTION OF MINIMALIST COMPOSITION TECHNIQUES IN SERBIAN MUSIC OF THE LATE $20^{\mathrm{TH}}$ CENTURY
}

\author{
Marija Masnikosa* \\ University of Arts in Belgrade \\ Faculty of Music \\ Department of Musicology
}

\begin{abstract}
This paper aims to present the whole range of different forms of reception of American minimalist composition techniques in the Serbian music in last quarter of the 20th century. Author's special attention is focused on the fact that the influence of American minimalism (and its techniques) on the Serbian 'new music' in this period was 'divided' into two branches - one group of the composers strictly followed the achievements of early American (modernist) minimalism, while the other composers created their individual responses to the challenges of American post-minimalism. Also, this paper points to the fact that, unlike the American minimalist genealogy, in which there was a historical continuity connecting the 'parent' modernist minimalism with post-minimalism, works of modernist and postmodernist minimalism appeared in the Serbian music of late 20th century almost simultaneously and independently.
\end{abstract}

Keywords: minimalism, post-minimalism, Serbian music, reception of minimalist composition techniques, discontinuity

* The author contact address: marija.masnikosa@gmail.com

The paper was written within the project Identiteti srpske muzike u svetskom kulturnom kontekstu [Identities of Serbian Music in the World Cultural Context], initiated by the Department of Musicology of the Faculty of Music in Belgrade and supported by the Ministry of Education, Science and Technological Development of the Republic of Serbia, under the Reg. No. 177019. 
Апстракт: Овај рад написан је с намером да прикаже читаву лепезу различитих видова рецепције америчког минимализма и минималистичких композиционих техника у српској музици последње четвртине 20. века. Посебна пажња посвећена је указивању на двојак утицај америчког минимализма на музику у Србији: једна група композитора креативно је одреаговала на остварења раног, модернистичког минимализма, док је друга група композитора индивидуално и међусобно независно одговарала на изазове америчког постминимализма. Тако се догодило да модернистички минимализам и постминимализам у српској музици последње четвртине 20. века нису били повезани логиком сукцесије и историјског континуитета (како је то изведено у америчкој музици), већ су се ове две значајне тенденције у српској музици појавиле готово истовремено и независно једна од друге.

Кључне речи: минимализам, постминимализам, српска музика, рецепција минималистичке композиционе технике, дисконтинуитет

The period of time that featured the emergence of the first achievements based on minimalist repetitive processes in Serbia, represented in the Serbian (in fact, then still Yugoslav) cultural context an unexpected and quite specific 'mix of different times' ${ }^{1}$ - the public display of an entire spectrum of various residual and rising artistic phenomena.

Serbian music of the latter part of the 1970s was marked by simultaneous, yet somehow separate coexistence of reverberations of neoclassicism in the works of composers of different generations, the neoexpressionist and neoimpressionist works of older composers, and the accomplishments of the "new music' embodied in various, individually found forms of expression of European and American modernist musical practice after the Second World War.

The first minimalist composition in Serbia, Melange (1975) by Vladimir Tošić, appeared in the mid-1970s. Almost concurrently, the collage of existing modernist tendencies was, within the framework of Serbian 'new music', joined by the first postmodern breakthroughs that included the earliest postminimalist music works - among them the very first being Epimetej [Epimetheus] for organ (1977) by Vlastimir Trajković.

Considering the fact that fifteen years had passed between the appearance of modernist minimalism and the first postminimalist works in American music, the simultaneity of modernistic minimalism and postminimalism in Serbian music is rather surprising and thus raises the question about the specific path of Serbian music history during the last quarter of the $20^{\text {th }}$ century.

${ }^{1}$ Cf. Hal Foster, The Return of the Real: The Avante-Garde at the End of the Century, An OCTOBER Book, Cambridge - London, MIT Press, 1996, 207. 
Masnikosa, M.: The Reception of Minimalist Composition Techniques ... (181-190)

The aim of this study is to outline the entire spectrum of various aspects of the reception of minimalism in Serbian music of the last quarter of the $20^{\text {th }}$ century, and, considering the cultural context of the given period, to partially elucidate the reasons for the almost concurrent but mutually unrelated appearances of modernist and postmodern minimalism in Serbian music.

The conditions for opening toward the 'world of art', as defined in the democratic civil societies of Western Europe and America, were created in Yugoslavia as early as the mid-1950s, following a period of socialist realism.

Yugoslav art music, striving toward its own 'progressive artistic mission'2 in the spirit of the then actual socialism, was initially (during the late 1950s and 1960s) dominated by the influence of the 'post-war European avant-garde', while the influence of the turbulent avant-garde events in the United States (also evident in our society since the 1950s) intensified only during the 1970s, after the initial blast of the American experimental neo-avant-garde had already passed.

During the 1970s, European and American influences (inevitably interrelated), rendered in Serbian 'new music' a variety of artistic expressions: the works of 'pure' musical medium and electronic music were dominated by the influence of European post-war 'new music', while the American experimental neo-avant-garde found the grounds for its influence mainly in the field of extended media, conceptual and minimalist art.

A certain number of composers, however, still nurtured the achievements of the 'outlived' post-war avant-garde, which in 1960s Serbia, from the aspect of compositional technique, was represented by the 'principles of integral serialism and dodecaphony as its ordinary precursor (...); the Polish composers' Krzysztof Penderecki's and Witold Lutoslawski's type of aleatoricism; and the micropolyphony technique, recognizable in the Hungarian composer György Ligeti.' 3

On the other hand, research in the area of the extended media, primarily in poly-media projects (initiated during the 1950s) of composer Vladan Radovanović, the founder of the 'experimental fraction' in Serbian music, acted as the neo-avant-garde critique of the (high-)modernistic autonomy of music as an art discipline. The activities of Vladan Radovanović particularly affected the members of the New Generation group, who (independently of Radovanović), through their travels to the West in the late 1970s and by acquiring books, scores, and audio materials, contracted the ideas of the post-war American avant-garde.

2 The expression coined by Mirjana Veselinović-Hofman. Cf. Mirjana Veselinović-Hofman, Teze za reinterpretaciju jugoslovenske muzičke avangarde [Theses on Reinterpretation of Yugoslav Musical Avant-Garde], Muzički talas, 30-31, 2002, 29.

3 Ibid., 27. 
Under the strong influence of the American experimental practice with whose achievements they were partially familiar, the young artists of the group New Generation made themselves known toward the end of the 1970s by the avant-garde critique of the Belgrade musical 'stage' as confined to the music medium. ${ }^{4}$

The activities of the composers gathered around the group New Generation (which afterward produced the group OPUS 4), took place in the atmosphere of conceptual art, ${ }^{5}$ and mostly 'off' stage of the Belgrade Student Cultural Centre ${ }^{6}$ which harboured encapsulated 'echoes' and meta-reflections of the latter part of the $20^{\text {th }}$-century American neo-avant-garde experiment. The members of the group were occupied with the 'phenomenon of expanded sound and extended media, inter-media, multi-media, performance, action, video, photography and film, semiosonic and metamusic, theory-object and integrated object, happening and pre-conceived piece, sound environment and illustration, the tape and slide.'

Around the 1980s, four members of the group New Generation - Vladimir Tošić (1949), Miodrag Lazarov Pashu (1949), Milimir Drašković (1952), and Miroslav Savić (1954) - founded a more coherent group and named it OPUS $4 .{ }^{8}$ They aligned themselves to a specific concept of creative work, which according to Lazarov (the OPUS 4 theoretician), coincided with the idea of opus ephemerum,

4 These young rebels made themselves heard through theory too: the manifest of their work - Miodrag Lazarov Pashu's text Nova generacija [New Generation] - was printed in the catalogue Muzički program Studentskog kulturnog centra [Student Culture Centre's Musical Programme] (Belgrade, SKC - Sava Centre, 1979). The attitude of the Nova generacija group members towards the institutionalized musical scene of Belgrade may be best portrayed by a 'composition' - a conceptual work Muzika u Beogradu [Music in Belgrade] (1978) by Milimir Drašković, embodied in a blank sheet of paper!

5 From 1975 to 1980, the activities of Student Cultural Centre in Belgrade included the efforts of conceptually oriented Grupa 143 [Group 143], whose members were Biljana Tomić, Miško Šuvaković, Jovan Čekić, Neša Paripović, Paja Stanković, Maja Savić, Vladimir Nikolić and Mirko Dilberović. Cf. Miško Šuvaković, Konceptualna umetnost [Conceptual Art], in: Pojmovnik moderne i postmoderne likovne umetnosti i teorije posle 1950. godine, Belgrade - Novi Sad, SANU - Prometej, 1999, 152.

6 Miroslav Miša Savić, a member of the Nova generacija, and later of the Opus 4 group, held the position of the musical director in the Student Cultural Centre in Belgrade, from 1979 to 1995.

7 Cf. Miodrag Lazarov Pashu, Opus 4, Moment, 17, 1990, 47.

8 Informally, the group existed even while the four young composers were students - the first public performance by what was to become the group Opus 4 took place in 1976, in the Hall of Student Cultural Centre. The group officially started its activity in February 1980, as an 'autonomna stvaralačka jedinica' ['autonomous creative unit'] within the New Generation. Cf. Miodrag Lazarov Pashu, Nova generacija [New Generation], in: Muzički program..., op. cit., 1-8; Miodrag Lazarov Pashu, Opus 4, Moment..., op. cit., 47-54. 
Masnikosa, M.: The Reception of Minimalist Composition Techniques ... (181-190)

as an 'open structure' susceptible to distraction, and opposed to the traditional Western European 'accomplished' artwork form, which does feature its 'beginning' and its 'end', and 'can at any time be bought and sold'.'

After the announcement of minimalism in the reductionist, proto-minimalist composition Four Chorales (1957) ${ }^{10}$ by Vladan Radovanović, a particular variant of 'integral serialism' appeared during the 1970s in the works of the OPUS 4 members.

While the practice of modernist minimalism was initiated in Serbia by the appearance of Tošić's ${ }^{11}$ unique and, in a sense, 'bordering' composition Melange (1975), it was his Fusion for 12 Instruments (1978) ${ }^{12}$ that could be considered a paradigm of the specifically Belgrade-grown, fully pre-arranged 'integral minimalism'. ${ }^{13}$

Each of the OPUS 4 composers created a unique minimalist method. The minimalist oeuvre of Vladimir Tošić is characterized by high complexity, precise note-to-note control, and ultimately strict gradual repetitive processes in the manner of Reich's paradigmatic works belonging to his hard-line minimalism. These specific repetitive processes include serialization of the music parameters (Fuzija [Fusion] for flute, Ne/Zavisnost [In/Dependency] for piano) and simultaneous work with the models of rhythmic and pitch values (Fusion

9 Ibid., 50.

10 Our musicological literature, most notably Mirjana Veselinović-Hofman's texts, state that this composition is minimalist. It is indeed based on a certain kind of extreme reduction that could be related to minimalism, but it cannot be comprehended as a 'true' minimalist work because it does not contain traces of minimalist processes. Namely, the clear presence of minimalist musical processes is a conditio sine qua non of any radical minimalist creation. This composition is not repetitive, nor does it stem from continuous non-repetitive minimalist processes counting on minimal changes in the domain of obligatorily reduced set of pitch classes, and hence I perceive this Radovanović's work, which was indeed avantgarde in our midst, as a reductionist, proto-minimalist, but not yet minimalist composition.

11 Composition Melange by Vladimir Tošić presents a theoretically difficult case: judging by the type of the chosen process - which is strict and symmetric, but not continuous or explicitly repetitive - it is difficult to determine whether it is a reductionist proto-minimalist work or a 'true' minimalist one. However, since a one-bar model for repetition nevertheless exists in this composition (isorhythmic reiteration of a single pitch), albeit not explicitly written, my opinion is that this work can be considered 'the point of departure' of the modernist minimalism in Serbian music. After slightly changing the original idea of this composition, Tošić in 1976 wrote the work Trajanje [Continuance] for 24 female voices, where minimalist repetitiveness was employed somewhat more explicitly.

12 For more extensive analysis of this composition and its significance for the practice of Belgrade ‘integral minimalism' cf. Marija Masnikosa, Muzički minimalizam [Musical Minimalism], Belgrade, Clio, 1998, 87-97.

13 The expression 'integral minimalism' taken from: Mirjana Veselinović, Stvaralačka prisutnost evropske avangarde u nas [Creative Presence of European Avant-garde in our Midst], Belgrade, Univerzitet umetnosti, 1983, 388. 
for 12 Instruments). Tošić's most important minimalist pieces from that period are Melange, Fusion for flute, Fusion for 12 Instruments, and the particularly unique composition In/Dependence. ${ }^{14}$

In his minimalist compositions, Miroslav Miša Savić achieved a more liberal and more flexible, although not necessarily less complex, concept of minimalism. His most significant minimalist accomplishment is certainly the design and realization of double-repetitive and simultaneously occurring, but differently directed processes (reduction/construction). Each process occurs within the one of the participating musical parameters - such as the pitch and syllable models in his composition ABC Music for Conga, for example. The repetitive algorithm in some of his works includes a certain degree of flexibility in regard to the changed, oscillatory repetition of the pitch models, but nevertheless maintains the strictness in repetition of the rhythmic models' 'series' (N.N. for Piano). Savić's works, although minimalist, generate a high degree of entropy and certainly do not represent the 'audible structures' proclaimed by hard-line American minimalism. ${ }^{15}$

Contrary to Tošić and Savić, Miodrag Lazarov Pashu turned toward 'simple' transparent minimalism characterized by the exact repetition of the given models and constant pitch basis throughout the composition, and further combined it with the concept of the postponed time, achieved in his works by the specific model anamorphosis. Apart from his composition Fonoserije/Identiteti [Phonoseries/Identities] (based on the manipulation of an augmented triad across different piano registers), the piece Vreme.1 [Time.1] for two timpani ${ }^{16}$ most clearly represents the isolated features of Pashu's minimalism.

The first minimalist work by Milimir Drašković was conceived only in 1988, whereas his minimalism stands chronologically and conceptually most distant from the strict paradigm of the early American minimalism. Drašković's minimalist processes are rather simple, based on the literal repetition of models or events within the model usually treated as a series. Drašković's tendency to choose the model-series that is susceptible to clear tonal codification as a basis for his compositions supersedes the context of strict modernist minimalism, thus distancing these works from the proclaimed minimalist position of contextual neutrality. The titles of his most significant works - the cycle under the composite name $H P S C H D^{17}$ - undoubtedly refer to those from the oeuvre of John Cage.

14 For more on these compositions cf. Marija Masnikosa, Muzički minimalizam, op. cit., 81-115.

15 For more on Miša Savić's compositions cf. ibid., 116-141.

16 More extensive coverage of Lazarov's minimalist opus in: ibid., 141-151.

17 Details on Milimir Drašković's minimalist opus in: ibid., 151-160. 
Belgrade minimalism achieved a specific difference in relation to the American paradigm of modernist minimalism only in terms of considering the repetitive model category as almost always conjoined with the series category, in the perception of the Belgrade minimalists. The model as a series exists in nearly all the works by Belgrade minimalist composers, except in those by Lazarov Pashu. In his Fusion for flute, for example, Tošić, even works with the unique minimalist 'quaternion'!

Overall, the specific modernist minimalism of the Belgrade composers was a site-specific 'converging point' of the post-war European affinity toward constructivism and the American concept of music minimalism. Some works of Belgrade integral minimalism are, by their degree of complexity in repetitive processes, comparable even to the complex, hidden repetitive procedures in the works of American postminimalism. ${ }^{18}$

Much like American minimalism in its homeland, the minimalism of the group OPUS 4 faced during the late 1970s and early 1980s the strong resistance of academia, which, among the new directions of contemporary music, only accepted those leading toward a progressively more complex organization of sound. The radical reduction, primarily in the field of the compositional technique imposed by the Belgrade OPUS 4 composers, seemed from the academic perspective to have been overly simplistic to be accepted. The emergence of integral minimalism among Belgrade composers, as the only clearly distinguished and defined formation within the New Generation group rebellion activities, triggered therefore an entirely expected eruption of the 'icono-vigilante' resistance camp. ${ }^{19}$

Consequences, naturally, followed: obstructed by the affective and restrictive ideological resistance of the musical establishment of the time, the Belgrade integral minimalism project - in itself already hostile toward compromise - remained isolated, and 'unfit' for Belgrade institutionalized musical life. By the actual music establishment as well as by its very creators, this project was seen as opposition to the institution of 'new music' in Serbia. The position of the 'opposite' indeed blocked the possibility of the direct influence Belgrade integral minimalism eventually could have exerted on the professional milieu. It thus happened that, unlike the direction in the lineage of American minimal-

\footnotetext{
18 Similar hidden double repetitive processes with cumulative changes can be found in some preludes from the cornerstone work of the American post-minimalism - The Time Curve Preludes (1977/78) by William Duckworth.

19 From the angle of the then-active 'educational team' of Faculty of Music in Belgrade, the antagonism towards radical reduction in the students' works was, first and foremost, 'the protection of the trade', and then the defence of their own artistic ideology which was indirectly 'attacked' by the young composers' action.
} 
ism, the Belgrade modernist minimalism did not assume a precursor role in the development of postminimalism in Serbian music.

Milimir Drašković, Miodrag Lazarov Pashu, Vladimir Tošić, and Miroslav Miša Savić, who, at the end of 1970s in Serbia, promoted 'hard' modernist minimalism, during the 1980s still composed (among other works) modernist minimalist music, largely neglecting to follow the new postmodern trends. Vladimir Tošić was, in fact, the only representative of the OPUS 4 group who would, only later, during the $1990 \mathrm{~s}$, accept the challenge of music postmodernism and reach into the field of postmodern minimalism.

Hence, except for the works of Vladimir Tošić ${ }^{20}$ (and that is as late as in the 1990s!), compared to the American music minimalist 'genealogy' manifested in the historical succession that connects 'parental' minimalism with postminimalism in the works of e.g. Phillip Glass and Steve Reich - Serbian music lacks such continuity.

The first postminimalist works in Serbian music were conceived as a creative reflection of the postminimalism by American composers, bypassing altogether the experiences of Belgrade integral minimalism. The overall energy needed to ignite postminimalism as a new direction in Serbian music was demonstrated by young composers who were able to 'hear' and accept the new and different postmodern challenges, ${ }^{21}$ and who, at the given time experienced and embodied their creative affinities within the postmodern transformation of minimalism. Consequently, the earliest postminimalist works in Serbia, in a paradoxical turn, belong to those composers who did not have a creative contact with radical modernist minimalism!

The performance of Glass's and Wilson's opera Einstein on the Beach at the Belgrade BITEF Theatre Festival in 1976 presented an incentive for the then young composers who lacked an individual creative experience with hard-line modernist minimalism. It was the way in which Phillip Glass 'reformulated' the strict minimalist repetitiveness that inspired younger composers to create less binding, 'freer' and more liberal minimalist processes, which - corresponding with the postmodern spirit - more or less included some elements and proce-

\footnotetext{
${ }^{20}$ His post-minimalism is firmly grounded in his own radical minimalism, which is by 'outside intervention' fused with post-modernist pseudo-referentiality. In that regard, his postminimalism is paradigmatic - it demonstrates 'stage zero' of the post-modernist minimalism, and in a completely different manner than the compositions of the authors who did not have personal experience of the radical minimalism. (More on this later on in the main text.)

${ }^{21}$ None of the protagonists of post-minimalism in Serbia was close to the ideas of the American post-war avant-garde! Their creativity embraced the minimalist technique, enriching it with a post-modernist 'grain' of freedom, which was alien to the proponents of modernist minimalism.
} 
Masnikosa, M.: The Reception of Minimalist Composition Techniques ... (181-190)

dures of older, pre-modernist musical practices. Along with the 'diagonal' repetitiveness based on the idea of the phase shifting and free repetitive procedures that also included the 'points of change' (as contrary to the rigid, monolithic totally controlled minimalist procedures in the works of the OPUS 4 members), the most successful postminimalist works of the late 1970s and the 1980s incorporated: a 'taste' of folklore (such as 'dancing' and 'singing' in Raskovnik by Vuk Kulenović), a semblance of baroque-type themes and imitative procedures (Cartoon by Zoran Erić), quotations of baroque music theme excerpts subjected to repetitive procedures (Misteriozne barikade [Les Barricades Mystérieuses] by Ana Mihajlović), various individually composed and conventionally codified thematic units and gestures (Rondo, Sekvenca III [Rondo, Sequence III] by Katarina Miljković, Run! by Ognjen Bogdanović, Mehanički Orfej [Mechanical Orpheus] by Vuk Kulenović), and a simulation of multi-layered, Mahleresque romantic themes subjected to the relentless minimalist repetitiveness (Konzertstück and Helijum u maloj kutiji [Helium in a Small Box] by Zoran Erić).

Serbian postminimalist musical practice embraced various combinations of repetitive technique and older, genre-differing 'musics'. The fact that Serbian postminimalist practice did not yield works that could be interpreted as individual replicas of the oeuvre of William Duckworth, John L. Adams or other American postminimalists whose works did not feature explicit intertextuality, could come as a surprise to some experts of American postminimalism.

In its individual formulations and unlike American postminimalism, Serbian musical postminimalism does not reflect an affinity toward the development of the actual minimalist technique. It rather comes as a result of an encounter with the works of Glass, Reich, Adams and others, and as a full acceptance of the minimalist repetitive technique that for composers of the younger generation has become the 'native musical language' and the foundation whereby (with the inclusion of fragments of 'other' musics and older compositional approaches) they can express their individual artistic sensibility.

Overall, Serbian postminimalist practice (presented here in a summarized form), did not exhibit a logical continuation in the development of minimalism in the local setting. The emergence of Serbian postminimalism was enacted by composers who were not modelled by the early, modernist American minimalism and did not continue on their path, but were instead, motivated by the highly renowned works of American postminimalism and chose minimalist technique as a 'ready-made' (in Adorno's sense) material upon which they could carry out their own individual poetical ideas.

The recent history of Serbian music therefore exhibits a sharp postmodern disconnect: unlike the causal and diachronic relationship of modernist minimal- 
ism and postminimalism in world music history and due to the significantly delayed arrival of minimalism in relation to its American predecessor, modernist minimalism and postminimalism entered Serbian music almost simultaneously and independently of one another! 